\title{
Activation of PKA, p38 MAPK and ERKI/2 by gonadotropins in cumulus cells is critical for induction of EGF-like factor and TACEI ADAMI 7 gene expression during in vitro maturation of porcine COCs
}

\author{
Yasuhisa Yamashita ${ }^{1}$, Mitsugu Hishinuma ${ }^{1}$ and Masayuki Shimada*2
}

\author{
Address: ${ }^{1}$ School of Veterinary Medicine, Faculty of Agriculture, Tottori University, 4-101 Koyamachou-minami, Tottori, 680-8553, Japan and \\ ${ }^{2}$ Graduate School of Biosphere Science, Hiroshima University, 1-4-4 Kagamiyama, Higashi-Hiroshima, 739-8528, Japan \\ Email: Yasuhisa Yamashita - yamayasu@muses.tottori-u.ac.jp; Mitsugu Hishinuma - mhishi@muses.tottori-u.ac.jp; \\ Masayuki Shimada* - mashimad@hiroshima-u.ac.jp \\ * Corresponding author
}

Published: 24 December 2009

Journal of Ovarian Research 2009, 2:20 doi:10.1 I86/1757-2215-2-20

This article is available from: http://www.ovarianresearch.com/content/2/I/20

(C) 2009 Yamashita et al; licensee BioMed Central Ltd.

This is an Open Access article distributed under the terms of the Creative Commons Attribution License (http://creativecommons.org/licenses/by/2.0), which permits unrestricted use, distribution, and reproduction in any medium, provided the original work is properly cited.
Received: 27 July 2009

Accepted: 24 December 2009

\begin{abstract}
Objectives: During ovulation, it has been shown that LH stimulus induces the expression of numerous genes via PKA, P38 MAPK, PI3K and ERKI/2 in cumulus cells and granulosa cells. Our recent study showed that EGF-like factor and its protease (TACE/ADAMI7) are required for the activation of EGF receptor (EGFR), cumulus expansion and oocyte maturation of porcine cumulusoocyte complexes (COCs). In the present study, we investigated which signaling pathways are involved in the gene expression of EGF-like factor and in Tace/Adam 17 expression in cumulus cells of porcine $\mathrm{COC}$ during in vitro maturation.
\end{abstract}

Methods: Areg, Ereg, Tace/Adam 17, Has2, Tnfaip6 and Ptgs2 mRNA expressions were detected in cumulus cells of porcine COCs by RT-PCR. Protein level of ERKI/2 phosphorylation in cultured cumulus cells was analyzed by westernblotting. COCs were visualized using a phase-contrast microscope.

Results: When COCs were cultured with FSH and LH up to $2.5 \mathrm{~h}$, Areg, Ereg and Tace/Adam 17 mRNA were expressed in cumulus cells of COCs. Areg, Ereg and Tace/Adam 17 gene expressions were not suppressed by PI3K inhibitor (LY294002), whereas PKA inhibitor (H89), p38 MAPK inhibitor (SB203580) and MEK inhibitor (U0I26) significantly suppressed these gene expressions. Phosphorylation of ERKI/2, and the gene expression of Has2, Tnfaip6 and Ptgs2 were also suppressed by H89, SB203580 and U0 I26, however, these negative effects were overcome by the addition of EGF to the medium, but not in the U0I26 treatment group.

Conclusion: The results showed that PKA, P38 MAPK and ERKI/2 positively controlled the expression of EGF-like factor and TACE/ADMAI7, the latter of which impacts the cumulus expansion and oocyte maturation of porcine COCs via the EGFR-ERKI/2 pathway in cumulus cells. 


\section{Background}

In mammals, luteinizing hormone (LH) stimulation induces morphological and physiological changes in granulosa cells and cumulus cells, causing them to progress to the ovulation process [1]. During this period, cumulus cells expressed cumulus expansion-related genes, Hyaluronan synthase 2 (Has2) [2,3], Tumor necrosis factor $\alpha$ induced protein 6 (Tnfaip6) $[4,5]$, and Pentraxin 3 (Ptx3) $[6,7]$, which is necessary for the synthesis and stability of hyaluronan-rich extracellular matrix. In Tnfaip6 null mice [5] or Ptx3 null mice [7], number of ovulated oocytes decreased and in vivo fertilization was completely interrupted, suggesting that cumulus expansion was essential for both ovulation and fertilization processes.

It is known that since LH receptor ( $\mathrm{Lhcgr}$ ) is mainly expressed in granulosa cells, the EGF-like factor produced in granulosa cells by LH surge acts on cumulus cells to induce cumulus expansion. Some factors were introduced to transmit the LH signal from granulosa cells to cumulus cells. For example, prostagrandin E2 (PGE2) that produced from granulosa cells and cumulus cells by prostagradin synthase 2 (PTGS2) was required for induction of Has2 and Tnfaip6 gene, cumulus expansion and oocyte meiotic resumption [8]. The EGF-like factors, Amphiregulin (AREG), Epiregulin (EREG) and $\beta$-cellulin (BTC) were also recently reported as potent factor. The EGF-like factor was induced by LH stimuli in granulusa cells, and EGF receptor (EGFR) was localized on cumulus cells [9-11]. When mouse COCs were cultured with AREG, Has2, Tnfaip6 and Ptgs2 were expressed in cumulus cells. TACE/ ADAM17, the cleavage enzyme of EGF-like factor to soluble forms, was also expressed in porcine granulosa cells in vivo in response to hCG administration [12]. Thus, in vivo during the ovulation process, LH induces EGF-like factor expression in granulosa cells and the release of the EGF domain by TACE/ADAM17 acts on cumulus cells, which induce cumulus expansion.

In in vitro maturation of oocytes, COCs were recovered from antral follicles and cultured with FSH and/or LH. We previously showed that FSH and LH up-regulate EGF-like factor and Tace/Adam17 mRNA expression, and gonadotropins-induced cumulus expansion and oocyte maturation of porcine COCs were suppressed by EGF receptor tyrosine kinase inhibitor or TACE/ADAM17 inhibitor [13]. The results suggested that FSH- and LH-induced cumulus expansion was dependent on the expression and functions of EGF-like factors. Although the regulation of EGF-like factor expression in cancer cell lines has been reported [14,15], the mechanisms of EGF-like factor and TACE/ADAM17 expression in cumulus cells cultured with FSH and/or LH have remained unclear during in vitro maturation of porcine COCs.
The binding of FSH and/or LH in granulosa cells to its own receptors led to rapidly and nongenomic activation of PKA, p38 MAPK, and PI3K in a cAMP-dependent manner [16] and of ERK1/2 via the SRC/RAS-dependent pathway [17]. In mice, since each inhibitor of PKA, p38 MAPK, PI3K or ERK1/2 suppressed the expression of cumulus expansion-related gene $[10,18,19]$, cumulus expansion $[18,19]$ or meiotic maturation of oocyte [20], we estimated that these signaling pathways induced by gonadotropin overlap the EGF-like factor-EGFR pathway, which induces full cumulus expansion and oocyte maturation.

In this study, to clarify the intracellular pathway involved in EGF-like factor and Tace/Adam 17 expression in cumulus cells, we examined the effect of PKA inhibitor (H89), p38 MAPK inhibitor (SB203580), PI3K inhibitor (LY294002) and MEK inhibitor (U0126) on Areg, Ereg and Tace/Adam 17 expression in cumulus cells during in vitro maturation of porcine COCs. Additionally, we investigated the effect of these drugs on ERK1/2 phosphorylation, cumulus expansion and oocyte meiotic resumption in pig.

\section{Methods \\ Materials}

High purified porcine FSH and porcine LH were gifts from the National Hormone and Pituitary Program (Rockville, MD, USA). Fetal calf serum (FCS) was obtained from Invitrogen (Carlsbad, CA, USA). Oligonucleotide poly- (dT) was purchased from Amersham Pharmacia Biotech (Newark, NJ, USA). Avian myeloblastosis virus reverse transcriptase and Taq DNA Polymerase were from Promega (Madison, WI). Routine chemicals and reagents were obtained from Nakarai Chemical Co. (Osaka, Japan) or Sigma (Sigma Chemical Co., St. Louis, MO, USA).

\section{In vitro culture of porcine COCs}

Isolation of porcine COCs was described previously [21]. Briefly, porcine ovaries were recovered from 5- to 7month-old prepubertal gilts at a local slaughterhouse. COCs were collected from the surfaces of intact healthy antral follicles measuring from 3 to $5 \mathrm{~mm}$ in diameter. The 20 COCs were cultured up to $40 \mathrm{~h}$ with both $20 \mathrm{ng} /$ $\mathrm{ml}$ highly purified porcine FSH (NIDDK, Torrance, CA) and $500 \mathrm{ng} / \mathrm{ml}$ porcine LH (NIDDK). The maturation medium was modified NCSU37 [22] supplemented with $10 \%$ (v/v) FCS (Gibco BRL, Grand Island, NY) and $7 \mathrm{mM}$ Taurine (Sigma St Louis, MO). At selected time intervals, COCs were collected for RNA and protein isolation.

The assessment of cumulus expansion was observed using phase-contrast microscopy (Olympus IMT2, Olympus, Tokyo Japan) and a 10× objective. 


\section{Treatment with inhibitors}

In the case of treatment with each specific inhibitor, namely PKA, H89 (10 uM) (Sigma), p38 MAPK, SB203580 (20 uM) (Sigma), PI3K, LY294002 (20 uM) (Sigma) or MEK, U0126 $10 \mathrm{uM}$ (Sigma), COCs were cultured for $0,2.5,5,10,20$ or $40 \mathrm{~h}$ with each of these inhibitors. $\mathrm{H} 89$ was dissolved in maturation medium at $10 \mathrm{mM}$ and stored at $-20^{\circ} \mathrm{C}$. SB203580, LY294002 and U0126 were dissolved in dimethylsulfoxide (DMSO) at $20 \mathrm{mM}$ and $10 \mathrm{mM}$, respectively, and stored at $-20^{\circ} \mathrm{C}$. The final concentration of each compound (as described above) was obtained by dilution $(1: 1000)$ with the maturation medium. The final concentration of vehicles (DMSO) was $0.1 \%$ ( $\mathrm{vol} / \mathrm{vol})$, which did not affect the function of cumulus cells during meiotic resumption of porcine oocytes [23].

\section{RNA isolation}

After cumulus cells were cultured, they were washed three times in PBS. Total RNA was extracted from cumulus cells using the SV Total RNA Isolation System (Promega) according to the instruction manual, and dissolved in nuclease-free water. The final RNA concentrations were determined by absorbance using a spectrophotometer.

\section{RT-PCR}

RT-PCR analyses were performed as previously described [22]. Briefly, total RNA was reverse-transcribed using 500 ng poly-dT and $0.25 \mathrm{U}$ of avian myeloblastosis virusreverse transcriptase at $42^{\circ} \mathrm{C}$ for $75 \mathrm{~min}$ and $95^{\circ} \mathrm{C}$ for 5 min. PCR conditions were set as follows: cDNA was amplified for X cycles (Table 1) of denaturation at $94^{\circ} \mathrm{C}$ for $30 \mathrm{sec}$, primer annealing at $\mathrm{Y}^{\circ} \mathrm{C}$ (Table 1) for $1 \mathrm{~min}$, and extension at $68^{\circ} \mathrm{C}$ for $1 \mathrm{~min}$, with a final extension step of $7 \mathrm{~min}$ at $68^{\circ} \mathrm{C}$. $\beta$-actin was used as a control for reaction efficiency and variations in concentration of mRNA in the original RT reaction. The amplified products were analyzed by electrophoresis on $2 \%$ agarose gels. The intensity of the objective bands was quantified by densitometric scanning using a Gel-Pro Analyzer. Specific primer pairs were selected and analyzed as indicated in Table 1.

\section{Western blot analysis}

Cumulus cells were lysed in Laemmli sample buffer and protein extracts were stored at $-80^{\circ} \mathrm{C}$ until use. After denaturing by boiling for $5 \mathrm{~min}, 10 \mathrm{ul}$ of each samples containing equal amounts of protein (10 ug) was separated by SDS-PAGE on $10 \%$ polyacrylamide gel, then transferred onto PVDF membrane (GE Healthcare). The membrane was blocked with 5\% (w/v) nonfat dry milk (GE Healthcare) in PBS. Primary antibodies were added in $2.5 \%(\mathrm{w} /$ v) nonfat dry milk in $0.1 \%(\mathrm{v} / \mathrm{v})$ Tween 20 (Sigma)/PBS (PBS-T), and incubated overnight at $4^{\circ} \mathrm{C}$. Anti-phosphoERK $1 / 2$ and $\beta$-ACTIN were purchased from Cell Signaling Technology, Inc (Beverly, MA) and diluted at 1:2,000 or $1: 10,000$, respectively. After four washes in PBS-T, the membranes were incubated for $1 \mathrm{~h}$ with a $1: 2,000$ dilution of goat anti-rabbit IgG HRP-linked antibody (Cell Signaling Technology, Inc) in $2.5 \%(\mathrm{w} / \mathrm{v})$ nonfat dry milk in PBS-T at room temperature. After five washes of $10 \mathrm{~min}$ each with PBS-T, peroxidase activity was visualized using the ECL Western blotting detection system (GE Healthcare) according to the manufacturer's instructions.

\section{Statistical analysis}

Statistical analyses of all data from three or four replicates for comparison were carried out by one-way ANOVA followed by Duncan's multiple-range test (Statview; Abacus Concepts, Inc., Berkeley, CA). All percentage data were subjected to arcsine transformation before analysis.

\section{Results}

Effect of each specific inhibitor of PKA, p38 MAPK, PI3K and MEK on the gonadotropin-induced Areg, Ereg and Tace/Adam I 7 mRNA expression during in vitro maturation of porcine COCs

COCs were cultured with FSH, LH and/or PKA inhibitor (H89), p38 MAPK inhibitor (SB203580), MEK inhibitor (U0126) or PI3K inhibitor (LY294002) for $2.5 \mathrm{~h}$. The results showed that high levels of Areg, Ereg and Tace/ Adam 17 mRNA were observed when COCs were cultured with FSH and $\mathrm{LH}$, and that the levels were not affected by LY294002 (Figure 1A, B, C). However, treatment with H89, SB203580 or U0126 significantly decreased these

Table I: List of primers employed for RT-PCR

\begin{tabular}{|c|c|c|c|c|}
\hline Gene & Forward Primer & Reverse Primer & $\begin{array}{c}\text { Anneling } \\
\text { temprature } \\
\text { (X) }\end{array}$ & Cycle (Y) \\
\hline -actin & 5'-CTA CAA TGA GCT GCG TGT GG-3' & 5'-TAG CTC TTC TCC AGG GAG GA-3' & 58 & 31 \\
\hline Areg & 5'-CAC CAG AAC AAA AAG GTT CTG TC-3' & 5'-AAG TCC ATG AAG ACT CAC ACC AT-3' & 58 & 35 \\
\hline Ereg & 5'AAG ACA ATC CAC GTG TGG CTC AAG-3' & 5'-CGA TTT TTG TAC CAT CTG CAG AAA-3' & 58 & 35 \\
\hline $\begin{array}{c}\text { Tacel } \\
\text { Adam I } 7\end{array}$ & 5'-GAC ATG AAT GGC AAA TGT GAG AAA C-3' & 5'-AGT CTG TGC TGG GGT CTT CCT GGA-3' & 58 & 34 \\
\hline Has2 & 5'-GAA TTA CCC AGT CCT GGC TT-3' & 5'-GGA TAA ACT GGT AGC CAA CA-3' & 54 & 35 \\
\hline Tnfaip6 & 5'-TCA TAA CTC CAT ATG GCT TGA AC-3' & 5'-TCT TCG TAC TCA TTT GGG AAG CC-3' & 54 & 32 \\
\hline Ptgs2 & 5'-CTG CCG TGT CGC TCT GCA CTG-3' & 5'-TCA TAA CTC CAT ATG GCT TGA AC-3' & 58 & 35 \\
\hline
\end{tabular}


mRNA expression levels in cumulus cells (Figure 1A, B, C).

\section{Effect of each specific inhibitor of PKA, p38 MAPK and MEK on ERKI/2 phosphorylation in cumulus cells during in vitro maturation of porcine COCs}

When COCs were cultured with FSH and $\mathrm{LH}$ for $5 \mathrm{~h}$, the phosphorylation status of ERK1/2 was detected. The addition of H89 or SB20580 to the medium significantly decreased the intensity of bands as compared with those in cumulus cells of COCs cultured without any inhibitor, and these inhibitory effects were overcome by addition of EGF (Figure 2). Treatment with U0126 also significantly suppressed ERK1/2 phophorylation in cumulus cells as compared with those in cumulus cells of COCs cultured without U0126; however, the addition of EGF to U0126contained medium did not affect the phosphorylation.

High levels of Has2, Tnfaip6 and Ptgs2 expression were observed in cumulus cells of COCs cultured for $10 \mathrm{~h}$ with FSH and LH as compared with those cultured without FSH and LH. The addition of H89, SB20580 or U0126 significantly suppressed FSH- and LH-induced Has2, Tnfaip6 and Ptgs2 expressions (Figure. 3A, B, C). Although the lower level of these gene expressions resulting from the addition of U0126 was not overcome by the addition of EGF, the addition of EGF to H89- or SB203580-containning medium overcame the negative effect of each inhibitor on these gene expressions (Figure. 3A, B, C).

\section{Effect of each specific inhibitor of PKA, p38 MAPK and MEK on meiotic resumption of oocytes and cumulus expansion during in vitro maturation of porcine COCs} When COCs were cultured without FSH and LH for $20 \mathrm{~h}$, the proportion of oocytes exhibiting GVBD was less than $25 \%$. FSH and LH significantly increased the proportion of oocytes exhibiting GVBD. This higher rate was significantly decreased by $\mathrm{H} 89$ or SB20580, and the suppression was counteracted by the addition of EGF (Figure 4). Treatment with U0126 also significantly suppressed the GVBD rate, whereas the addition of EGF did not overcome the negative effects.

The culture of COCs with FSH and LH for $40 \mathrm{~h}$ induced the full expansion of COCs (Figure. 5). The expansion was completely suppressed by treatment with H89, SB20580 or $\mathrm{U} 0126$ for $40 \mathrm{~h}$. Although the negative effects of H89 and SB20580 were overcome by the addition of EGF, the treatment with EGF did not overcome the negative effects of U0126.

\section{Discussion}

Recently, it has been showed that the novel paracrine/ autocrine factors expressed in granulosa cells and cumulus cells by LH stimuli acted on cumulus cells to induce cumulus expansion, meiotic maturation of oocytes and ovulation in mouse [9-11]. Since the suppression of the EGF receptor tyrosine kinase activity by specific inhibitor completely suppressed cumulus expansion and meiotic maturation of oocytes during in vitro maturation of mouse COCs [9], the EGF-like factor was quite important for ovulatory process. During in vitro maturation of porcine COCs, the addition of EGF to maturation medium significantly elevated developmental competence of oocytes to blastocyst stage [12], indicating that investigation of the transcriptional mechanism of the EGF-like factor and TACE/ADAM17 was essential for not only ovulatory process, but also cytoplasamic maturation of oocyte.

It has been reported that during the ovulation process the PKA-dependent pathway involving the ligand activation of $\mathrm{G}$ protein-coupled receptors by their ligands in cumulus and/or granulosa cells induced the expression of ovulation-related genes, including Cyp11a1 [24], Star [25] and Ptgs2 [26]. Other reports documented that, in rat granulosa cells, FSH and LH up-regulated the phosphorylation of p38 MAPK by a PKA-independent mechanism that might be involved in Epac [27]. Furthermore, a recent report showed that FSH nongenomically activates ERK1/2 via SRC/RAS dependent pathway in rat granulosa cells [17], indicating that the activation of ERK1/2 was not directly activated by cAMP-activated PKA or p38 MAPK pathway. In this study, when porcine COCs were cultured for $2.5 \mathrm{~h}$ with PKA inhibitor, p38 MAPK inhibitor or MEK inhibitor, FSH- and LH-induced Areg, Ereg, and Tace/ Adam 17 mRNA expressions were significantly suppressed. In osteoblastic cells, the promoter region of the Areg gene had a putative CRE site, and the region was quite important for parathyroid hormone-induced Areg gene induction via CREB phosphorylation [28]. In rat granulosa cells, it has been reported that the phosphorylation of CREB was induced by FSH within 1.5 h [29]. Our recent study showed in rat granulosa cells that phosphorylation of CREB was induced by FSH dependent manner and the phosphorylation of CREB was essential for transcription of Areg mRNA via its promoter region of CRE site (Shitanaka et al., unpublished data). We also showed in granulose-specific Erk1/2 knockout mice that Areg expression level was significantly lower than that in wild-type mice [30]. It is known that CREB has the sites phosphorylated by ERK1/2 and p38 MAPK [31,32]. Thus, at early in the process, p38 MAPK and ERK1/2 might be involved in the phosphorylation of CREB, which would induce Areg gene expression in cumulus cells of porcine COCs.

Our previous study showed that EGFR tyrosine kinase inhibitor or TACE/ADAM17 inhibitor suppressed the phosphorylation of ERK1/2 and the meiotic resumption of oocytes [13]. In this study, the addition of EGF to PKA 

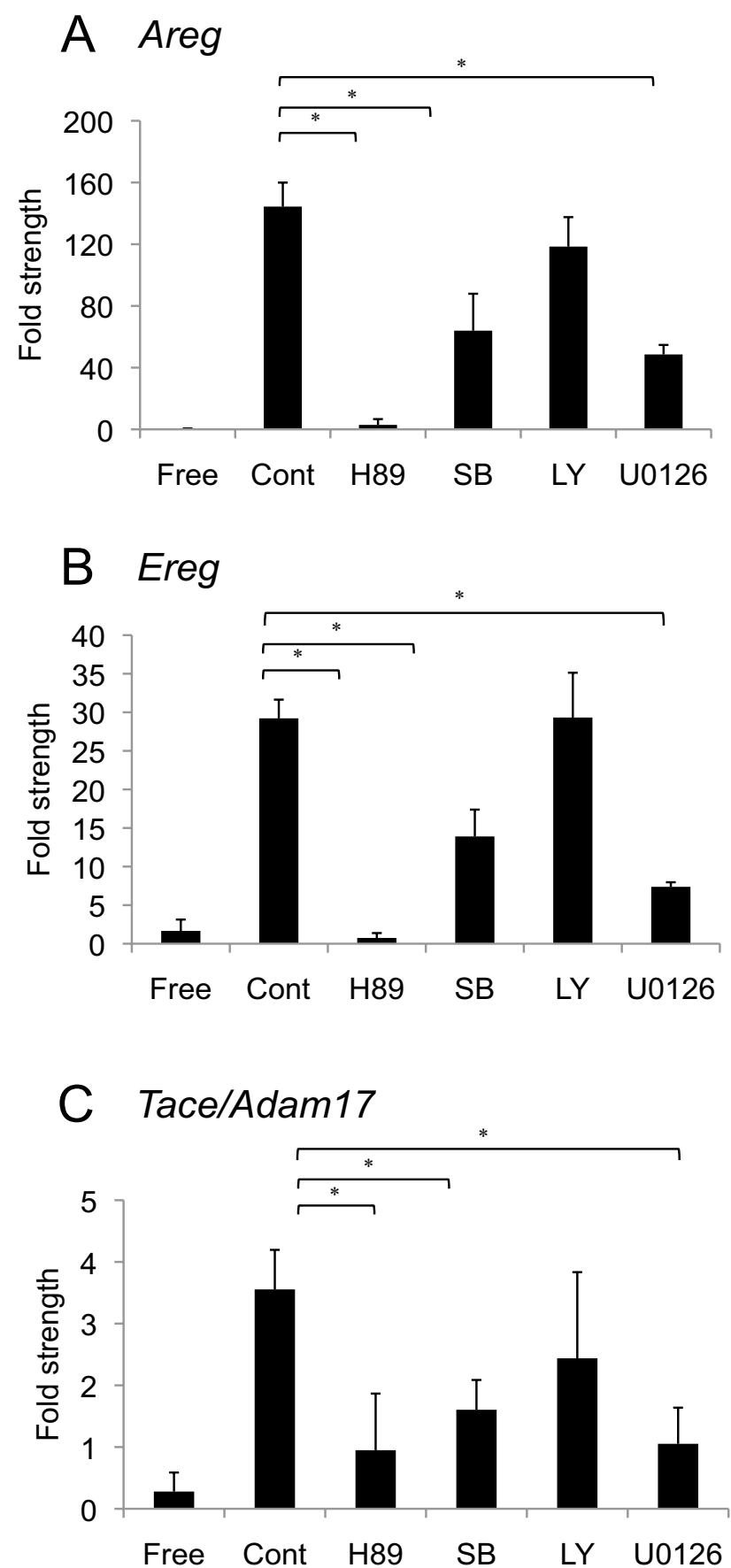

Figure I

Effect of H89, SB203580, LY294002 or U0I 26 on Areg(A), Ereg(B) or TacelAdam I 7(C) mRNA. For reference, the $0 \mathrm{~h}$ COC value was set as I and the data presented as the fold strength. Values are mean $+/-$ SEM of 3 replicates. *: The significant differences were observed as compared with that in COCs cultured with FSH and LH for 2.5 h. The respective value of among Areg, Ereg, and Adam 17 mRNA were normalized according to those of -actin mRNA to evaluate arbitrary units of the relative abundance of the targets. Free: $\mathrm{COCs}$ were cultured without FSH and LH for $2.5 \mathrm{~h}$; Cont: COCs were cultured with FSH and LH for 2.5 h; H89: COCs were cultured with FSH, LH and H89 for $2.5 \mathrm{~h}$; $\mathrm{SB}$ : COCs were cultured with FSH, LH and SB203580 for 2.5 h; LY: COCs were cultured with FSH, LH and LY294002 for 2.5 h; U0I26: COCs were cultured with FSH, $\mathrm{LH}$ and U0I26 for $2.5 \mathrm{~h}$ 


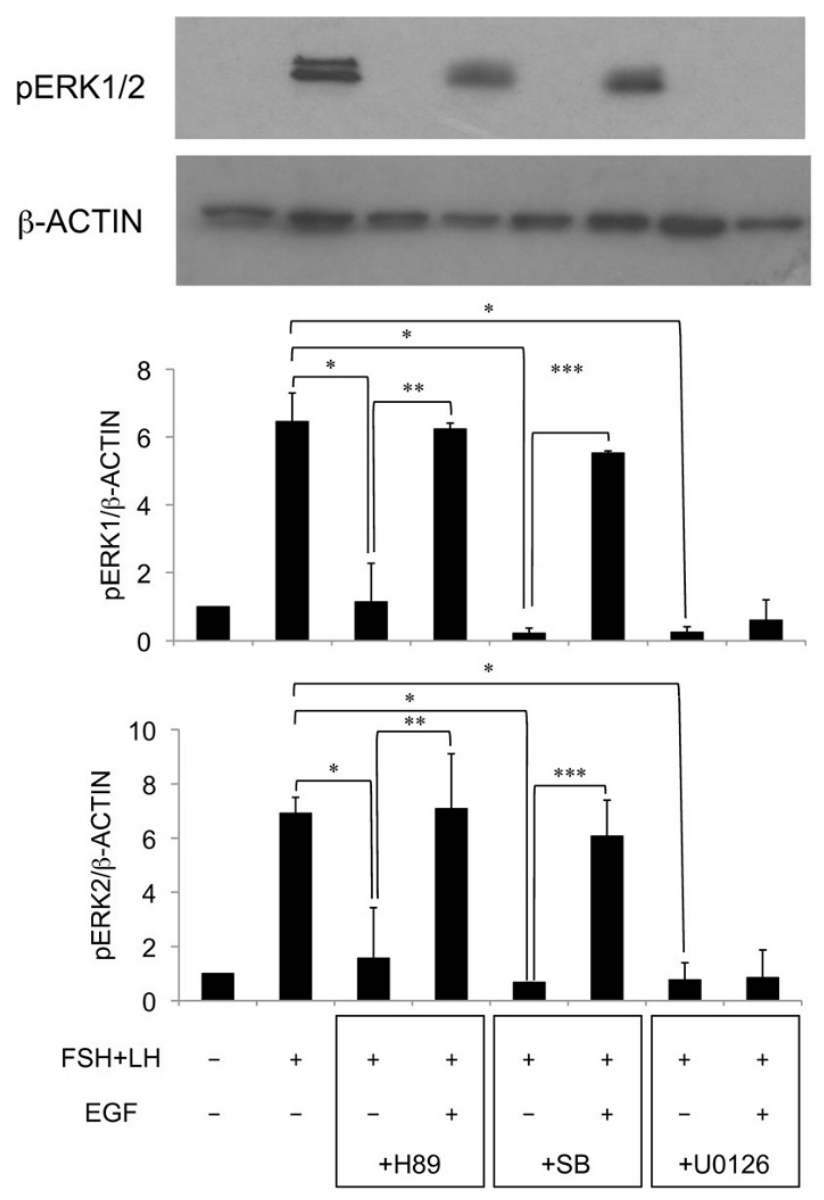

Figure 2

Effect of H89, SB203580 or U0 I 26 on ERKI/2 phosphorylation in cumulus cells. For reference, the COC that were cultured without FSH and $\mathrm{LH}$ for $5 \mathrm{~h}$ value was set as I and the data presented as the fold strength. Values are mean +/- SEM of 3 replicates. *: The significant differences were observed as compared with that in COCs cultured with FSH and LH for $5 \mathrm{~h}$. **: The significant differences were observed as compared with that in COCs cultured with $\mathrm{FSH}$, LH, H89 and EGF for $5 \mathrm{~h}$. ***: The significant differences were observed as compared with that in COCs cultured with FSH, LH SB230580 and EGF for $5 \mathrm{~h}$. The respective value of protein levels of ERKI/2 phosphorylation were normalized according to those of $\beta$-ACTIN to evaluate arbitrary units of the relative abundance. $\mathrm{FSH}(-)$ : $\mathrm{COCs}$ were cultured without $\mathrm{FSH}$ and $\mathrm{LH}$ for $5 \mathrm{~h} ; \mathrm{FSH}(+)$ : $\mathrm{COCs}$ were cultured with FSH and LH for $5 \mathrm{~h}$; EGF(-): COCs were cultured without EGF for $5 \mathrm{~h}$; $\mathrm{EGF}(+)$ : COCs were cultured with EGF for $5 \mathrm{~h}$; +H89: COCs were cultured with $\mathrm{H} 89$ for $5 \mathrm{~h}$; +SB: COCs were cultured with SB203580 for $5 \mathrm{~h}$; +U0 126: COCs were cultured with U0I 26 for $5 \mathrm{~h}$
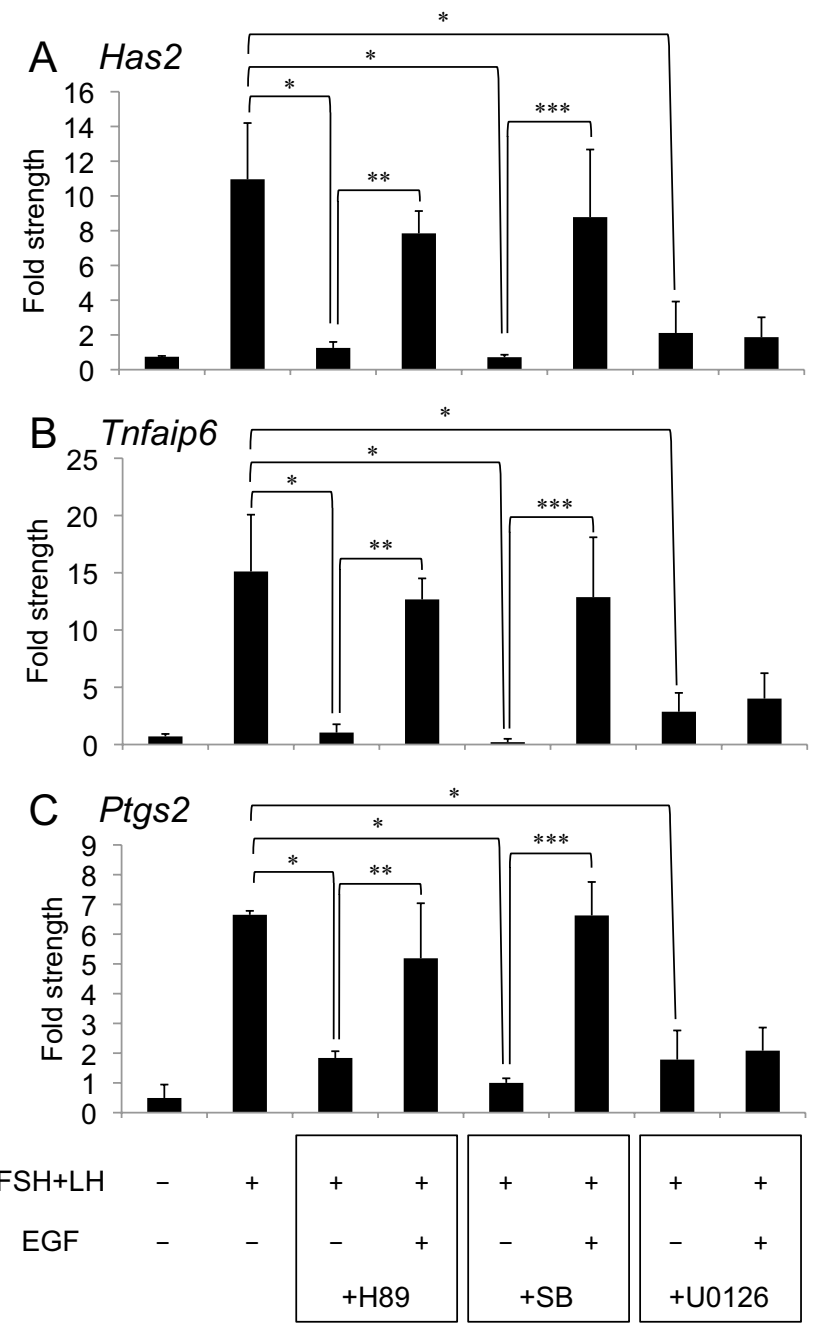

Figure 3

Effect of H89, SB203580 or U0I 26 on expression of Has2(A), Tnfaip6(B) or Ptgs2(C) mRNA. For reference, the $0 \mathrm{~h} \mathrm{COC}$ value was set as I and the data presented as the fold strength. Values are mean +/- SEM of 3 replicates. *: The significant differences were observed as compared with that in COCs cultured with FSH and LH for $10 \mathrm{~h}$. **: The significant differences were observed as compared with that in COCs cultured with FSH, LH, H89 and EGF for $10 \mathrm{~h}$. ***:

The significant differences were observed as compared with that in COCs cultured with FSH, LH, SB230580 and EGF for $10 \mathrm{~h}$. The respective value of among Has2, Tnfaip6 and Ptgs2 mRNA were normalized according to those of -actin mRNA to evaluate arbitrary units of the relative abundance of the targets. $\mathrm{FSH}(-)$ : $\mathrm{COCs}$ were cultured without $\mathrm{FSH}$ and $\mathrm{LH}$ for $10 \mathrm{~h} ; \mathrm{FSH}(+)$ : $\mathrm{COCs}$ were cultured with $\mathrm{FSH}$ and $\mathrm{LH}$ for $10 \mathrm{~h}$; EGF(-): COCs were cultured without EGF for $10 \mathrm{~h}$; EGF $(+)$ : COCs were cultured with EGF for $10 \mathrm{~h} ;++\mathrm{H} 89$ : COCs were cultured with $\mathrm{H} 89$ for $10 \mathrm{~h}$; $+\mathrm{SB}$ : COCs were cultured with SB203580 for $10 \mathrm{~h}$; +U0 I26: COCs were cultured with U0I 26 for $10 \mathrm{~h}$ 


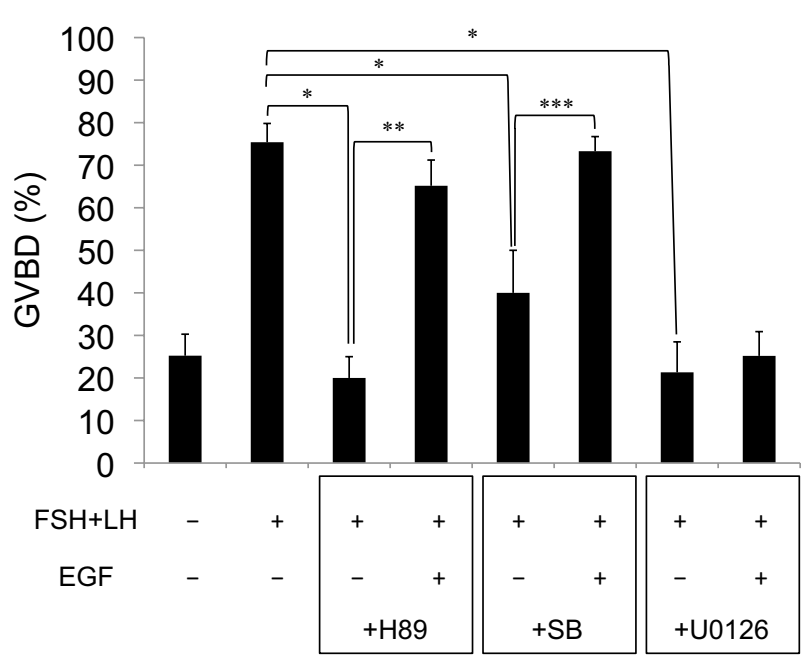

Figure 4

Effect of H89, SB203580 or U0I26 on rate of oocyte exhibiting GVBD. Values are mean +/- SEM of 3 replicates. *: The significant differences were observed as compared with that in COCs cultured with FSH and LH for $20 \mathrm{~h}$. **: The significant differences were observed as compared with that in $\mathrm{COCs}$ cultured with FSH, LH, $\mathrm{H} 89$ and EGF for $20 \mathrm{~h}$. ***: The significant differences were observed as compared with that in COCs cultured with FSH, LH, SB230580 and EGF for 20 h. FSH(-): COCs were cultured without FSH and $\mathrm{LH}$ for $20 \mathrm{~h}$; $\mathrm{FSH}(+)$ : COCs were cultured with $\mathrm{FSH}$ and $\mathrm{LH}$ for 20 h; EGF(-): COCs were cultured without EGF for 20 h; EGF(+): COCs were cultured with EGF for $20 \mathrm{~h}$; +H89:

COCs were cultured with $\mathrm{H} 89$ for $20 \mathrm{~h}$; $+\mathrm{SB}$ : COCs were cultured with SB203580 for $20 \mathrm{~h}$; +U0I26: COCs were cultured with U0I 26 for $20 \mathrm{~h}$

or p38 MAPK inhibitor-containing medium overcame the negative effects or cumulus expansion and oocyte meiotic resumption. However, when COCs were cultured with U0126, the treatment with EGF did not overcome the U0126 effects. Thus, the MEK-ERK1/2 pathway played dual roles in cumulus cells. One role is the induction of EGF-like factor and TACE/ADAM17 expression. The other is direct induction of cumulus expansion of porcine COCs. In granulosa cell specific Erk1/2 knockout mice, the cumulus expansion was completely suppressed via the low induction of Ptgs 2 expression. In this study, the Ptgs2 expression level was suppressed by U0126, suggesting that EGF-like factor was required for the induction of cumulus expansion and oocyte meiotic resumption in porcine COCs as well as in mice.

\section{Conclusion}

Herein, we showed that the expression of EGF-like factor and TACE/ADAM17 in cumulus cells was induced by a PKA-, p38 MAPK- and ERK1/2-dependent mechanism during in vitro maturation of porcine COCs. The intracel-

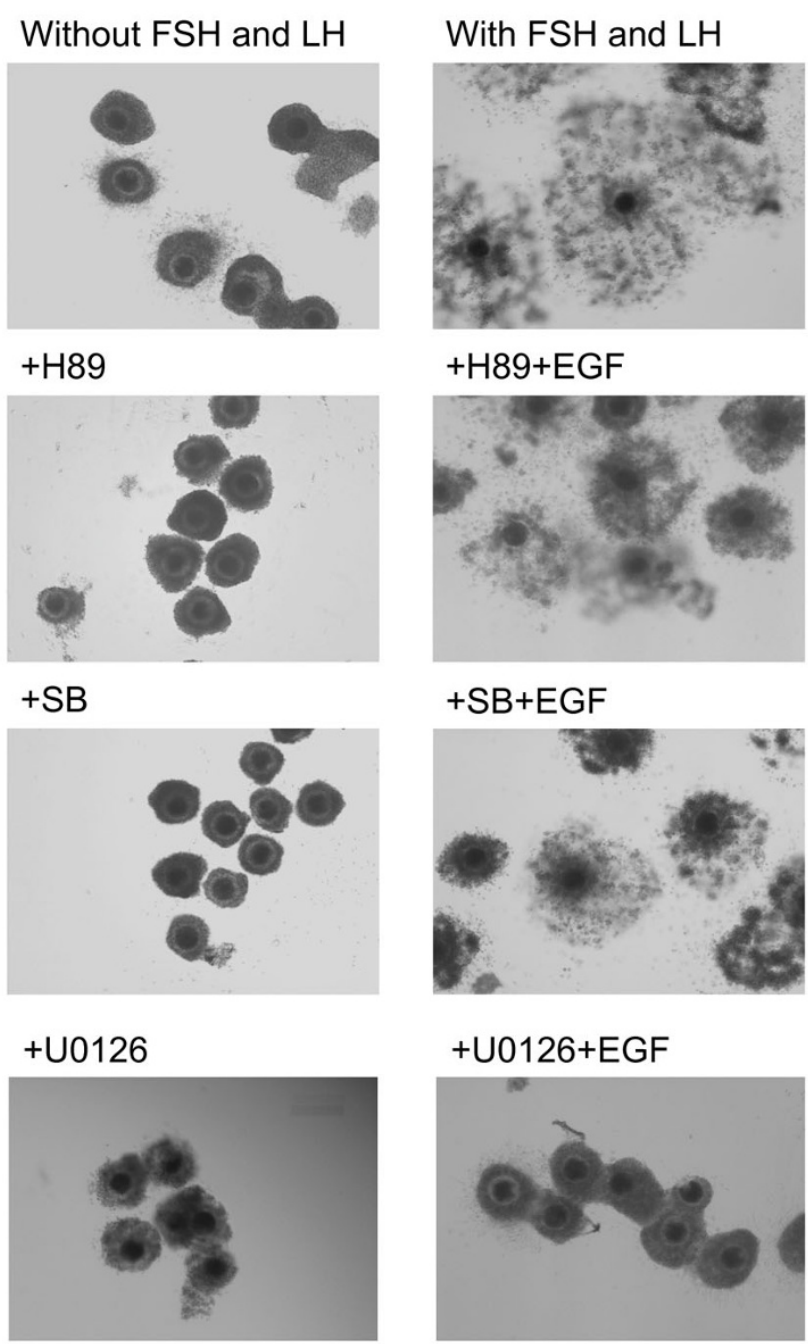

Figure 5

Effect H89, SB203580 or U0I 26 on cumulus expansion of cultured COCs. Without FSH and LH: COCs were cultured without FSH and $\mathrm{LH}$ for $40 \mathrm{~h}$; With FSH and $\mathrm{LH}$ : COCs were cultured with FSH and $\mathrm{LH}$ for $40 \mathrm{~h}$; $+\mathrm{H} 89$ : COCs were cultured with FSH, $\mathrm{LH}$ and $\mathrm{H} 89$ for $40 \mathrm{~h}$; $+\mathrm{H} 89+\mathrm{EGF}: \mathrm{COCs}$ were cultured with $\mathrm{FSH}, \mathrm{LH}, \mathrm{H} 89$ and EGF for $40 \mathrm{~h}$; +SB: COCs were cultured with FSH, LH and SB203580 for $40 \mathrm{~h}$; +SB+EGF: COCs were cultured with FSH, LH, SB and EGF for $40 \mathrm{~h}$; +U0I26: COCs were cultured with FSH, LH and U0I26 for $40 \mathrm{~h}$; +U0I26+EGF: COCs were cultured with FSH, LH, U0I26 and EGF for $40 \mathrm{~h}$.

lular mechanism of induction of the expression of EGFlike factor and TACE/ADAM17 further induce EGF-like factor and Tace/Adam17 mRNA expressions in cumulus cells via ERK1/2 activation. Thereby, the ERK1/2 maintained its activity via the EGF domain-EGFR-ERK1/2 pathway, which resulted in full cumulus expansion, and oocyte maturation during in vitro maturation of porcine COCs. 


\section{Abbreviations}

FSH: follicle stimulating hormone; LH: luteinizing hormone; EGF-like factor: epidermal growth factor-like factor; TACE/ADAM17: tumor necrosis factor $\alpha$ converting enzyme/a disinteglin and metalloptotease 17; Has2: hyaluronan synhase 2; Tnfaip6; tumor necrosis factor $\alpha$ induced protein 6; Ptx3: pentraxin 3; PGE2: prostagrandin E2; PTGS2; prostagrandin synthase 2; AREG; amphiregulin; EREG: epiregulin; BTC: $\beta$-cellulin; EGFR: EGF receptor; hCG: human chorionic gonadotropin; COC: cumulus-oocyte complex; PKA: protein kinase A; p38 MAPK: p38 mitogen-activated protein kinase; PI3K: phosphatidylinositol 3-kinase; ERK: extracellular-signal regulated protein; SRC: rous sarcoma oncogene; RAS: rat sarcoma viral oncogene.

\section{Competing interests}

The authors declare that they have no competing interests.

\section{Authors' contributions}

YY and MS conceived of the study, participated in its design and coordination and drafted the manuscript. All authers read and approved the final manuscript.

\section{Acknowledgements}

Supported, in part, by grant-in-Aid for Scientific Research (Y.Y., No. 19880020) and (M.S., No. I8688016) from the Japan Society for the Promotion of Science (JSPS). Porcine FSH and LH were kindly provided by Dr. A.F. Parlow, the National Hormone and Pituitary Program, the National Institute of Diabetes and Digestive and Kidney Disease, USA. We thank Mr. I Kawashima, Mr. T. Mizukami, Mr. T. Koike, and Ms. M. Okamoto for technical assistance. We also thank the staff of the Meat Inspection Office in Hiroshima City and Tottori prefecture for supplying the porcine ovaries.

\section{References}

I. Richards JS: Ovulation: new factors that prepare the oocyte for fertilization. Mol Cell Endocrinol 2005, 234:75-79.

2. Camaioni A, Hascall VC, Yanagishita M, Salustri A: Effects of exogenous hyaluronic acid and serum on matrix organization and stability in the mouse cumulus cell-oocyte complex. J Biol Chem 1993, 268:20473-2048I.

3. Chen L, Russell PT, Larsen WJ: Functional significance of cumulus expansion in the mouse: roles for the preovulatory synthesis of hyaluronic acid within the cumulus mass. Mol Reprod Dev 1993, 34:87-93.

4. Ochsner SA, Day AJ, Rugg MS, Breyer RM, Gomer RH, Richards JS: Disrupted function of tumor necrosis factor-alpha-stimulated gene 6 blocks cumulus cell-oocyte complex expansion. Endocrinology 2003, 144:4376-4384.

5. Fulop C, Szanto S, Mukhopadhyay D, Bardos T, Kamath RV, Rugg MS, Day AJ, Salustri A, Hascall VC, Glant TT, Mikecz K: Impaired cumulus mucification and female sterility in tumor necrosis factor-induced protein-6 deficient mice. Development 2003, 130:2253-226I.

6. Varani S, Elvin JA, Yan C, DeMayo J, DeMayo FJ, Horton HF, Byrne MC, Matzuk MM: Knockout of pentraxin 3, a downstream target of growth differentiation factor-9, causes female subfertility. Mol Endocrinol 2003, 16: I I54- I I67.

7. Salustri A, Garlanda C, Hirsch E, De Acetis M, Maccagno A, Bottazzi B, Doni A, Bastone A, Mantovani G, Beck Peccoz P, Salvatori G, Mahoney DJ, Day AJ, Siracusa G, Romani L, Mantovani A: PTX3 plays a key role in the organization of the cumulus oophorus extracellular matrix and in in vivo fertilization. Development 2004, I 3 I: I577-I586.
8. Ochsner SA, Russell DL, Day AJ, Breyer RM, Richards JS: Decreased expression of tumor necrosis factor-alpha-stimulated gene 6 in cumulus cells of the cyclooxygenase- 2 and EP2 null mice. Endocrinology 2003, 144:1008-1019.

9. Park JY, Su YQ, Ariga M, Law E, Jin SL, Conti M: EGF-like factor as mediators of $\mathrm{LH}$ action in the ovulatory follicle. Science 2004, 303:682-684.

10. Shimada M, Hernandez-Gonzalez I, Gonzalez-Robayna I, Richards JS: Paracrine and autocrine regulation of epidermal growth factor-like factors in cumulus oocyte complexes and granulosa cells: key roles for prostaglandin synthase 2 and progesterone receptor. Mol Endocrinol 2006, 20: |352-| 365.

II. Hsieh M, Lee D, Panigone S, Horner K, Chen R, Theologis A, Lee DC, Threadgill DW, Conti M: Luteinizing hormone-dependent activation of the epidermal growth factor network is essential for ovulation. Mol Cells Biol 2007, 27:19|4-1924.

12. Kawashima I, Okazaki T, Noma N, Nishibori M, Yamashita Y, Shimada $\mathrm{M}$ : Sequential exposure of porcine cumulus cells to $\mathrm{FSH}$ and/ or LH is critical for appropriate expression of steroidogenic and ovulation-related genes that impact oocyte maturation in vivo and in vitro. Reproduction 2008, 136:9-12.

13. Yamashita Y, Kawashima I, Yanai Y, Nishibori M, Richards JS, Shimada $M$ : Hormone-induced expression of tumor necrosis factor alpha-converting enzyme/A disintegrin ad metalloptotease17 impacts porcine cumulus cell oocyte complex expression and meiotic maturation via activation of the epidermal growth factor receptor. Endocrinology 2007, I 48:6I64-6I75.

14. Zhang Q, Thomas SM, Lui VW, Xi S, Siegfried JM, Fan H, Smithgall TE, Mills GB, Grandis JR: Phosphorylation of TNF-alpha converting enzyme by gastrin-releasing peptide induces amphiregulin release and EGF receptor activation. Proc Natl Acad Sci USA 2006, 103:690I-6906.

15. Thomas SM, Bhola NE, Zhang Q, Contrucci SC, Wentzel AL, Freilino ML, Gooding WE, Siegfriend JM, Chan DC, Grandis JR: Cross-talk between $G$ protein-cuopled receptor and epidermal growth factor receptor signailig pathways contributes to growth and invation of head and neck squamous cell carcinoma. Cancer Res 2006, 66: I1831-11839.

16. Richards JS: New signaling pathways for hormones and cyclic adenisine 3', 5'-monophosphate action in endocrine cells. Mol Endocrinol 200I, I5:2009-2018.

17. Wayne CM, Fan HY, Cheng X, Richards JS: Follicle-stimulating hormone induces multiple signaling cascades: evidence that activation of Rous sarcoma oncogene, RAS, and the epidermal growth factor receptor are critical for granulosa cell differentiation. Mol Endocrinol 2007, 21 : 1940-1957.

18. Downs SM, Hunzicker-Dunn M: Differential regulation of oocyte maturation and cumulus expansion in the mouse oocytecumulus cell complex by site-selective analogs of cyclic adenosine monophosphate. Dev Biol 1995, I72:72-85.

19. Su YQ, Denegre JM, Wigglesworth K, Pendola FL, O'Brien MJ, Eppig $\mathrm{JJ}$ : Oocyte-dependent activation of mitogen-activated protein kinase (ERK I/2) in cumulus cells is required for the maturation of the mouse oocyte-cumulus cell complex. Dev Biol 2003, 263: I 26-138.

20. Hoshino Y, Yokoo M, Yoshida N, Sasada H, Matsumoto H, Sato E: Phosphatidylinositol 3-kinase and Akt participate in the FSH-induced meiotic maturation of mouse oocytes. Mol Reprod Dev 69:77-86.

21. Yamashita Y, Shimada M, Okazaki T, Maeda T, Terada T: Production of progesterone from de novo-synthesized cholesterol in cumulus cells and its physiological role during meiotic resumption of porcine oocytes. Biol Reprod 2003, 68: I I 93-I I 98.

22. Yamashita $Y$, Nishibori M, Terada T, Isobe N, Shimada M: Gonadotropin-induced delta | 4-reductase and delta7-reductase gene expression in cumulus cells during meiotic resumption of porcine oocytes. Endocrinology 2005, 146:186-194.

23. Shimada M, Anas MKI, Terada T: Effects of phosphotidylinositol 3-kinase inhibitors, wortmannin and LY29 on germinal vesicle breakdown (GVBD) in porcine oocytes. J Reprod Dev 4002, 44:28I-288.

24. Sher N, Yivgi-Ohana N, Orly J: Transcriptional regulation of the cholesterol side chain cleavage cytochrome $P 450$ gene (CYPI IAI) revisited: binding of GATA, cyclic adenosine 3', 5 '-monophosphate response element-binding protein and activation protein (AP)-I proteins to a distal novel cluster of 
cis-regulatory element potentiates AP-2 and steroidogenic factor-I-dependent gene expression in the rodent placenta. Mol Endocrinol 2007, 21 1:948-962.

25. Yivgi-Ohana N, Sher N, Melamed-Book N, Eimerl S, Koler M, Manna PR, Stocco DM, Orly J: Transcriptional of steroidogenic acute regulatory protein in the rodent ovary and placenta: alternative modes of cyclic adenosine 3', 5'-monohposphate dependent and independent regulation. Endocrinology 2009, I 50:977-989.

26. Wu YL, Wiltbank MC: Transcriotional regulation of the cyclooxygenase-2 gene changes form protein kinase (PK) A to PKC-dependent after luteinazation of granulosa cells. Biol Reprod 2002, 66:1505-1514.

27. Gonzalez-Robayna IJ, Fakender AE, Ochsner S, Firestone GL, Richards JS: Follicle-Stimulating hormone (FSH) stimulates phosphorylation and activation of protein kunase B (PKB/Akt) and serum and glucocorticoid-induced kinase (Sgk): evidence for A kinase-independent signaling by FSH in granulosa cells. Mol Endocrinol 2000, I4:1283-1300.

28. Qin L, Partridge NC: Stimulation of amphiregulin expression in osteoblastic cells by parathyroid hormone requires the protein kinase $A$ and cAMP response element-binding protein signaling pathway. J Cell Biochem 2005, 96:632-640.

29. Carlone DL, Richards JS: Functional interactions, phosphorylation, and levels of 3', 5'-cyclic adenosine monophosphateregulatory element binding protein and steroidogenic factor-I mediate hormone-regulated and constitutive expression of aromatase in gonadal cells. Mol Endocrinol 1997, I I:292-304.

30. Fan HY, Liu Z, Shimada M, Sterneck E, Johnson PF, Hedrick SM, Richards JS: MAPK3/I (ERKI/2) in ovarian granulosa cells are essential for female fertility. Science 2009, 324:938-94I.

31. Lochner A, Marais E, Genade S, Huisamen B, du Toit EF, Moolman JA: Protection of the ischaemic heart: investigations into the phenomenon of ischaemic preconditioning. Cardiovasc J Afr 2009, 20:43-51.

32. Xing J: Coupling of RAS-MAPK pathway to gene activation by RSK2, a growth factor-regulated CREB kinase. Science 1996, 273:959-963.

Publish with Bio Med Central and every scientist can read your work free of charge

"BioMed Central will be the most significant development for disseminating the results of biomedical research in our lifetime. "

Sir Paul Nurse, Cancer Research UK

Your research papers will be:

- available free of charge to the entire biomedical community

- peer reviewed and published immediately upon acceptance

- cited in PubMed and archived on PubMed Central

- yours - you keep the copyright

Submit your manuscript here:

http://www.biomedcentral.com/info/publishing_adv.asp
BioMedcentral 